\title{
Growth and Yield of Black Locust (Robinia pseudoacacia L.) Stands in Nyírség Growing Region (North-East Hungary)
}

\author{
Károly Rédei ${ }^{1 \Xi}$, Imre Csiha ${ }^{1}$, Zsolt Keserü ${ }^{1}$, János Rásó ${ }^{1}$, \\ Ágnes Kamandiné Végh ${ }^{1}$, Borbála Antal ${ }^{2}$
}

\begin{abstract}
${ }^{1}$ National Agricultural Research and Innovation Centre, Forest Research Institute, Püspökladány Experimental Station, Farkassziget 3, Püspökladány 4150, Hungary

2 University of Debrecen, Faculty of Agricultural and Food Sciences and Environmental Management, Böszörményi 138, Debrecen 4032, Hungary
\end{abstract}

$\triangle$ Corresponding author: e-mail: redei.karoly@t-online.hu

\section{Citation:}

RÉDEI K, CSIHA I, KESERÜ ZS, RÁSÓ J, KAMANDINÉ VÉGH A, ANTAL B 2014 Growth and Yield of Black Locust (Robinia pseudoacacia L.) Stands in Nyírség Growing Region (North-East Hungary). South-east Eur for 5 (1): 13-22. DOI: http://dx.doi.org/10.15177/seefor.14-04

\section{Abstract}

Background and Purpose: In Hungary the black locust (Robinia pseudoacacia L.) can be considered as the most important fast-growing stand-forming exotic tree species. Due to its favourite growing technological characteristics as well as its wood utilization possibilities the present area occupied by black locust stands amounts to 460 thousand hectares. Of its growing districts Nyírség (NorthEast Hungary) has a distinguished importance where the area of black locust stands is appr. 22700 hectares. The Nyírség region can also be considered as one of the best black locust growing regions in the Carpathian basin. To determine their growth rate and yield as exact as possible a local numerical yield table has been constructed on the basis of surveys of the experimental plots established in pure, managed black locust stands.

Material and Methods: The local black locust yield table was constructed from data gathered on 105 sampling plots with average area of $1000 \mathrm{~m}^{2}$. The total area of the experimental plots was $9.295 \mathrm{ha}$. In the course of the stand surveys the key stand characteristics were measured, and then, on the basis of data collected, were calculated the average height, diameter (DBH), volume, basal area and stem number given separately for the main (remaining), secondary (removal) and total stands per hectare.

Results and Conclusion: Black locust yield table presented in this paper is the first local one in the history of the Hungarian black locust research. The programmable editing procedure allows extension and formal change of information content of the yield table according to different demands. This type of yield tables (standards) somewhat reflects the local growing-technological (forest tending) characteristics better way, on the other hand refer to the trend of quality and quantity changing of black locust stands growing in a given area.

Keywords: Black locust (Robinia pseudoacacia L.) stands, growth, local yield table 


\section{INTRODUCTION}

Black locust (Robinia pseudoacacia L.) was introduced to Europe from its natural range in south-eastern United States more than 300 years ago. It has been well adapted for growth in a wide variety of ecological conditions and planted throughout the world from temperate to subtropical areas. It is fast growing, excellent coppicing, drought tolerant, has high survival rates and yield as well as very hard durable wood. Due to its symbiosis with the nitrogen fixing bacteria, Rhizobium sp. black locust is capable of colonising very low nutrient substrates. Black locust is also a promising tree species for short rotation forestry (SRF) including energy plantations. The development of an integrated landscape includes forests, agricultural fields and shelterbelts. In these cases afforestation with black locust is focused on improving the natural environment and the living conditions of the population as well $[1,2]$.

In Hungary, black locust has played a role of great importance in the forest management for more than 280 years, covering approximately $24 \%$ of the forested area (460 000 ha) and providing about $20 \%$ of the annual timber output of the country. Being aware of the importance of black locust, forest research in Hungary has been engaged in resolving various problems of black locust management for a long time, and numerous research results have already been implemented in the practice [3-8]. In the country in the lowlands characterized with forest steppe climatic type, the annual precipitation is not more than $500 \mathrm{~mm}$, most of which is outside the growing season. Thus, drought is a frequent phenomenon in the summer period coupled with very high atmospheric temperatures. Due to these facts about $40 \%$ of the black locust stands in Hungary grow under marginal site conditions $[9,10]$. Several countries have started research programmes on improving black locust wood quality and/or increasing production of biomass for energy purpose. Black locust has also been considered as a promising tree species for animal feeding and for recultivation of drying out devastated lands as well as nectar production.
At present, black locust breeding and improvement is undertaken in the United States $[11,12]$ Greece [13], Germany [14, 15], Slovakia [16], Poland [17], Turkey [18], India [19, 20], China [21] and South Korea [22]. Increasingly number of countries are interested in black locust improvement and management paying special attention to its response to climate change effects. In the future there are two regions where the fast spread of black locust can be expected. In Europe the Mediterranean countries (Italy, Greece and Turkey), while in Asia China and Korea may become the most prominent black locust growers [23].

On the other hand it can be said that the literature reviews related to the yield and above ground dendromass of black locust stands have primarily domestic aspects [3, 24-27] with moderate international communication [2831].

\section{MATERIALS AND METHODS}

The Nyírség black locust growing district can be found in the north-eastern part of Hungary. The main ecological conditions of the region: forest-steppe climate where the relative air humidity between 50 and 55\%, hydrology: free draining, dominant soil type: humus sand soil, annual precipitation varies between 500 and $550 \mathrm{~mm}$. One of the main characteristics of the region is the large temperature fluctuation which is a very typical feature of the continental climate. Besides the cold winters and hot summers the daily variation is also very significant factor.

The yield table was constructed from data gathered on 105 subcompartments (sampling plots) (Figure 1). The sampling plots in pure, managed black locust stands were square shaped, their area $1000 \mathrm{~m}^{2}$ on average and their boundaries were marked by lasting white paint. The total area of the experimental plots was 9.295 ha. The following parameters were measured in the plots: number of stems, tree height, dbh (diameter at breast height) over bark. We classified each tree according to 
their height (1-4) and tending operation (1-3) classes.

On the basis of data, the average height, diameter $(\mathrm{DBH})$, volume $(\mathrm{V})$, basal area $(\mathrm{G})$ and stem number $(\mathrm{N})$ were calculated separately for the main (remaining), secondary (removal) and total stands per hectare.

Stem volume was estimated by the following volume function (Sopp-Kolozs, 2000) [27]:

$$
\begin{aligned}
& v=10^{-t} d^{2} h^{\prime}(h /[h-1.3])^{2} \\
& {[-0.6326 d h+20.23 d+0.0 h+3034]}
\end{aligned}
$$

where

$v$ is stem volume $\left(\mathrm{m}^{3}\right)$,

$d$ is diameter at breast height $(\mathrm{cm})$,

$h$ is tree height (m).

In the course of separating the main (remaining) and secondary (removal) stands, the principles and regulations of the national black locust tending operation model were taken into consideration, namely:

a. the ecological conditions and the continuation of basal area and the stem number per hectare close to the optimum at different periods of the growing cycle depending on the growing target,

b. production of the target assortments during the shortest possible time by controlling of certain factors of the stand structure.

TABLE 1. Distribution of the measured stands by age groups

\begin{tabular}{ccc}
\hline $\begin{array}{c}\text { Age group } \\
\text { (years) }\end{array}$ & $\begin{array}{c}\text { Number of } \\
\text { stands }\end{array}$ & $\begin{array}{c}\text { Rate } \\
(\%)\end{array}$ \\
\hline $1-5$ & 2 & 1.9 \\
$6-10$ & 10 & 9.5 \\
$11-15$ & 9 & 8.6 \\
$16-20$ & 13 & 12.4 \\
$21-25$ & 13 & 12.4 \\
$26-30$ & 18 & 17.1 \\
$31-35$ & 19 & 18.1 \\
$36-40$ & 10 & 9.5 \\
$41-45$ & 5 & 4.8 \\
$46-50$ & 6 & 5.7 \\
\hline Total & 105 & 100.0 \\
\hline
\end{tabular}
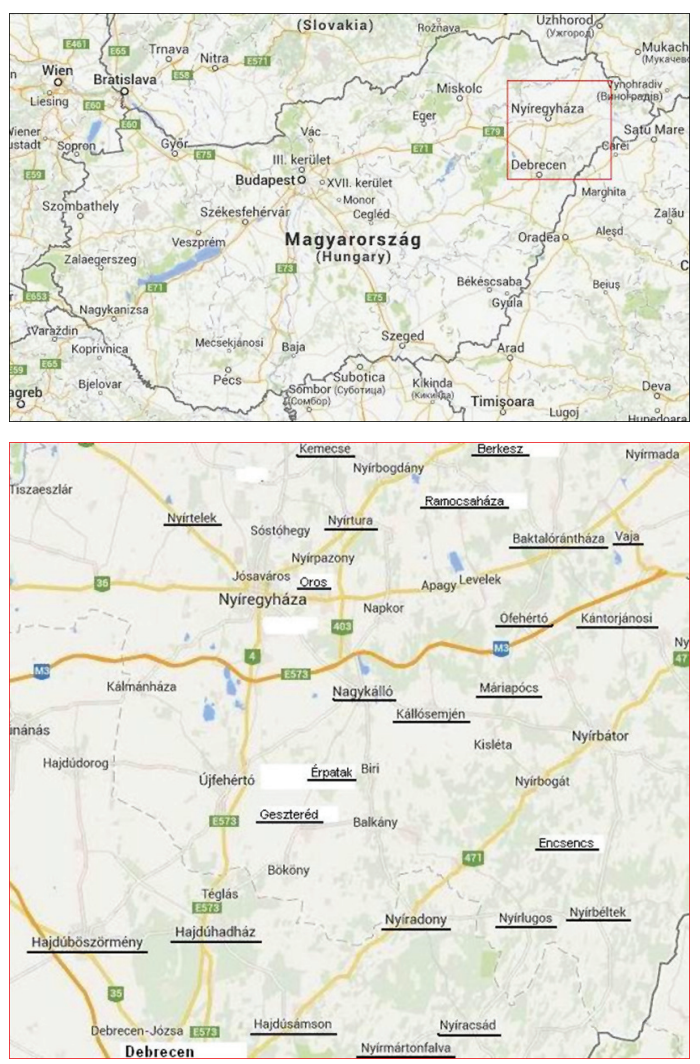

FIGURE 1. Locations of the sampling plots

The age and origin of the measured stands were identified on the basis of the particular forest management plans (Table 1, 2).

Yield class is called the intensity of height growth of a given stand compared to the all same tree species of the country, from best to worst from I to VI marked by Roman numerals (stands are classified into the yield class I-VI).

TABLE 2. Distribution of the measured stands by yield class [26]

\begin{tabular}{ccc}
\hline Yield class & $\begin{array}{c}\text { Number of } \\
\text { stands }\end{array}$ & $\begin{array}{c}\text { Rate } \\
(\%)\end{array}$ \\
\hline I & 26 & 24.7 \\
II & 36 & 34.3 \\
III & 23 & 21.9 \\
IV & 14 & 13.3 \\
V & 3 & 2.9 \\
VI & 3 & 2.9 \\
\hline Total & 105 & 100.0 \\
\hline
\end{tabular}




\section{RESULTS}

The yield table was constructed from data measured on 105 stands. To control main basic correlation of the yield table construction (mean height of the main stand plotted against the age) further 90 data of the Hungarian Forest Research Institute stand survey made for other purposes were also used. Evaluation of the data proved that as a mean height growth pattern of main stand of the investigated black locust stands can be considered analogous with that of the Hungarian national black locust yield table $[26,32]$ (Figure 2).

The numerical yield table contains the main stand structural and yield data with respect to the main-, removal and total stands divided into six, equal relative height growth pattern and equal bandwidth yield class (Table 3 ).

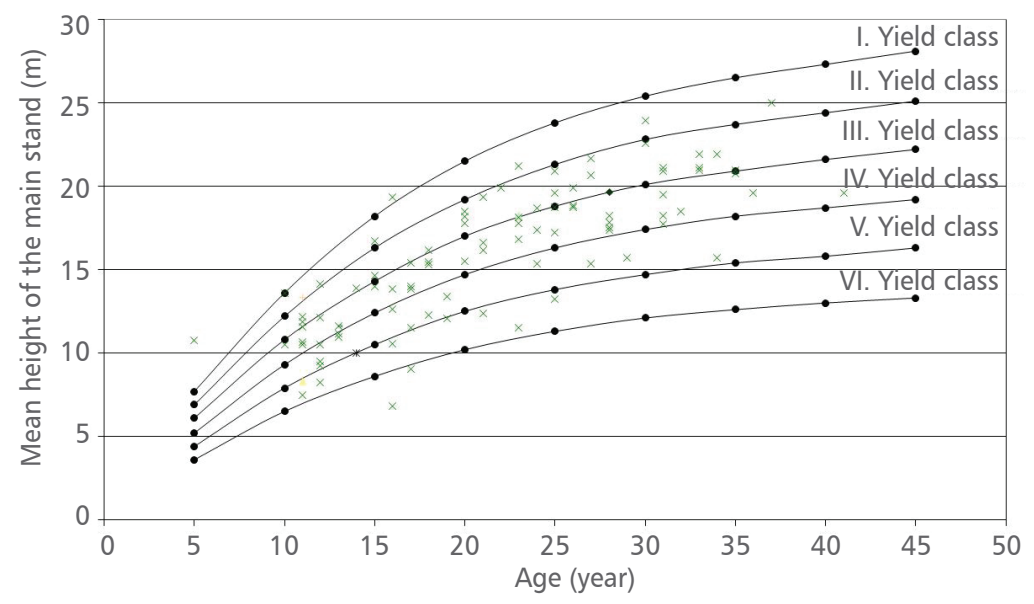

FIGURE 2. Standard deviation of height growth plotted against the age and the mean height of the main stand (Yield classes: Hungarian national yield tables [26, 32])

TABLE 3. Yield table for black locust stands (Nyírség)

\begin{tabular}{|c|c|c|c|c|c|c|c|c|c|c|c|c|c|c|c|c|c|c|c|c|}
\hline \multirow{3}{*}{ 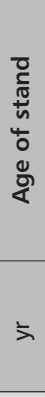 } & \multicolumn{5}{|c|}{ Main remaining stand } & \multicolumn{5}{|c|}{ Removal stand } & \multicolumn{5}{|c|}{ Total stand } & \multirow{2}{*}{  } & \multirow{2}{*}{ 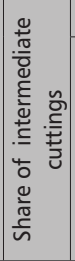 } & \multicolumn{3}{|c|}{ Total yield } \\
\hline & \multicolumn{2}{|c|}{ Average } & \multirow{2}{*}{ 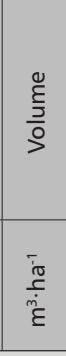 } & \multirow{2}{*}{ 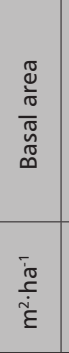 } & \multirow{2}{*}{ 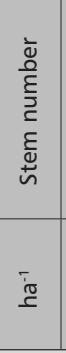 } & \multicolumn{2}{|c|}{ Average } & \multirow{2}{*}{  } & \multirow{2}{*}{ 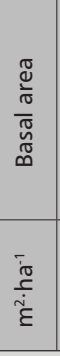 } & \multirow{2}{*}{ 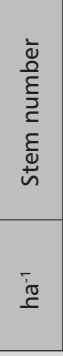 } & \multicolumn{2}{|c|}{ Average } & \multirow{2}{*}{ 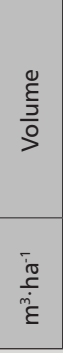 } & \multirow{2}{*}{ 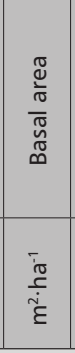 } & \multirow{2}{*}{  } & & & \multirow[t]{2}{*}{$\frac{\stackrel{0}{\xi}}{\frac{3}{0}}$} & \multirow{2}{*}{ 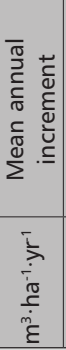 } & \multirow{2}{*}{ 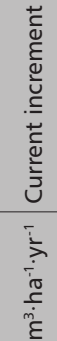 } \\
\hline & $\varepsilon$ & દે & & & & $\varepsilon$ & દે & & & & $\varepsilon$ & छ & & & & $\begin{array}{l}\text { Tू } \\
\dot{p} \\
\stackrel{\rho}{\xi}\end{array}$ & $\therefore$ & & & \\
\hline \multicolumn{21}{|c|}{ Yield class I. } \\
\hline 5 & 7.7 & & 33 & 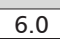 & 1887 & 5.8 & 3.4 & 8 & 1.5 & 1587 & 7.2 & 52 & 41 & 7.5 & 3474 & 0 & 198 & 41 & 8.3 & 0.0 \\
\hline 10 & 13.6 & 11.9 & 84 & 10.7 & 963 & 10.4 & \begin{tabular}{|l|}
8.0 \\
\end{tabular} & 37 & 4.6 & 924 & 13.1 & 10.2 & 121 & 15.4 & 1887 & 45 & 34.7 & 129 & 12.9 & 17.5 \\
\hline 15 & 187 & & 141 & & 673 & 138 & & 20 & & 290 & & & 169 & 17.6 & 963 & 73 & 34.3 & 214 & 14.3 & 17. \\
\hline 20 & 21.5 & 20.6 & 194 & 17.8 & 535 & 16.4 & 14.0 & 23 & 2.1 & 138 & 20.8 & 19.4 & 217 & 19.9 & 673 & 97 & 33.2 & 291 & 14.5 & 15.4 \\
\hline 25 & & & 241 & & 457 & 18.2 & & 18 & & 78 & & 22.8 & 259 & 21.9 & 535 & 115 & 32.2 & 356 & 14.2 & 130 \\
\hline 30 & 25.4 & 26.5 & 280 & 22.4 & 407 & 19.4 & 17.0 & 14 & 1.1 & 50 & 24.7 & 25.6 & 294 & 23.6 & 457 & 129 & 31.5 & 409 & 13.6 & 10.6 \\
\hline 35 & & 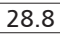 & 312 & 24.2 & 373 & 20.2 & & 11 & 0.8 & 34 & 25.8 & 28.0 & 323 & 25.1 & 407 & 140 & 30.9 & 452 & 12.9 & 8.7 \\
\hline 40 & 27.3 & 30.8 & 341 & 25.8 & 347 & 20.8 & 18.4 & 9 & 0.7 & 26 & 26.6 & 30.1 & 350 & 26.5 & 373 & 149 & 30.4 & 490 & 12.3 & 7.6 \\
\hline 45 & 28.1 & 32.8 & 369 & 27.3 & 323 & 21.4 & 19.0 & 9 & 0.7 & 24 & 27.3 & 32.1 & 378 & 28.0 & 347 & 158 & 30.0 & 527 & 11.7 & 7.5 \\
\hline
\end{tabular}


TABLE 3. Yield table for black locust stands (Nyírség) - continuation

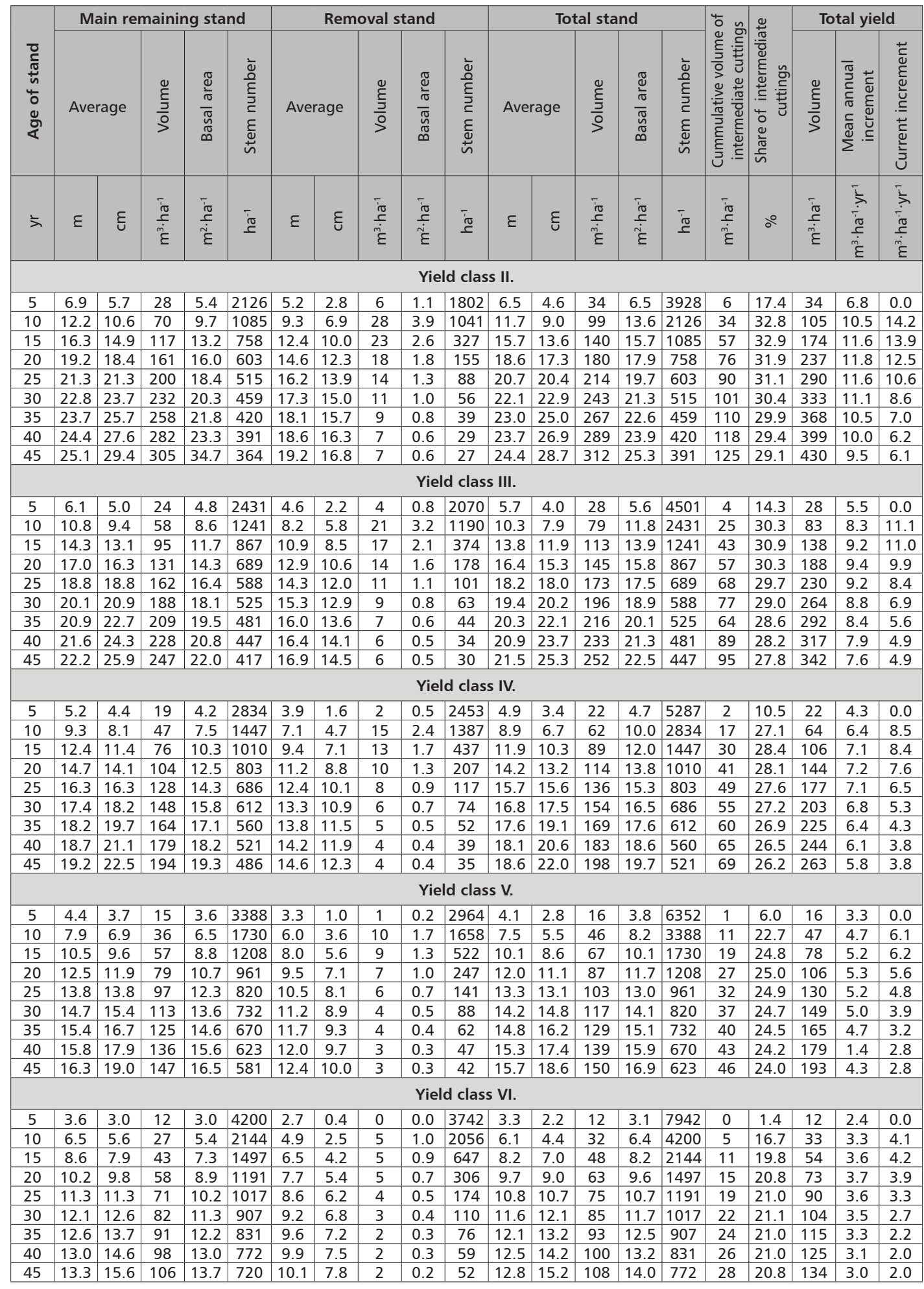


Editing procedure of the yield table in the order of columns is the following:

1. Age of stand $(A)$,

2. $H_{m}=$ average height of main (remaining) stand (height of dominant and codominant trees) in $\mathrm{m}$ :

$H_{m \%}=0.07940+7.19170 \cdot A-0.16029 \cdot A^{2}+0.00130 \cdot A^{3}$

(base age: 25 year, where $\mathrm{H}_{\mathrm{m} \%}=100$ )

3. $D_{m}=$ average $\mathrm{DBH}$ of main (remaining) stand in $\mathrm{cm}$ :

$$
\begin{aligned}
& D m=(78.78434+0.84862 \cdot A) H_{m} / 100 \\
& (r=0.799, n=105)
\end{aligned}
$$

4. $V_{m}=$ volume of main (remaining) stand in $\mathrm{m}^{3} \cdot \mathrm{ha}^{-1}$ :

$$
V_{m}=B A_{m} \cdot H \cdot F
$$

where $\mathrm{H} \times \mathrm{F}=$ form-height quotient

$H \times F=2.52726+0.39091 \mathrm{Hm}$,

$(r=0.989, n=105)$

5. $\mathrm{BA}_{\mathrm{m}}=$ basal area of main (remaining)stand in $\mathrm{m}^{2} \cdot \mathrm{ha}^{-1}$ :

$$
B A_{m}=\frac{D \cdot \Pi}{4 \cdot 10000} \cdot N_{m}
$$

6. $\mathrm{N}_{\mathrm{m}}=$ stem number of main (remaining)

stand in ha $^{-1}$ :

$$
\begin{aligned}
& N_{m}=e^{9.52993-1.07376 \ln D} \\
& (r=0.952, n=105)
\end{aligned}
$$

7. $H_{r}=$ average height of removal stand in $m$ :

$$
\begin{aligned}
& H_{r}=-0.08079+0.76572 \cdot H_{m} \\
& (r=0.941, n=105)
\end{aligned}
$$

8. $D_{r}=$ average $D B H$ of removal stand in $\mathrm{cm}$ :

$$
\begin{aligned}
& D_{r}=-2.39714+0.76294 \cdot H_{m} \\
& (r=0.939, n=105)
\end{aligned}
$$

9. $V_{r}=$ volume of removal stand in $m^{3} \cdot h^{-1}$ :

$$
V_{r}=B A_{r} \cdot H \cdot F_{m}
$$

10. $\mathrm{BA}_{\mathrm{r}}=$ basal area of removal stand in $\mathrm{m}^{2} \cdot \mathrm{ha}^{-1}$ :

$B A_{r}=\frac{D_{r}^{2} \cdot \Pi}{4 \cdot 10000} \cdot N_{r}$

11. $N_{r}=$ stem number of removal stand computed from reduction of stem number of main crop in five year intervals in ha-1

12. $H_{t}=$ average height of total stand in $\mathrm{m}$ :

$$
\begin{aligned}
& H_{t}=-0.28441+0.98240 \cdot H_{m} \\
& (r=0.998, n=105)
\end{aligned}
$$

13. $\mathrm{D}_{\mathrm{t}}=$ average $\mathrm{DBH}$ of total stand in $\mathrm{cm}$ :

$$
D_{t}=\frac{B A_{t} \cdot 10000}{N_{t} \cdot \Pi} \cdot 2
$$

14. $V_{t}=$ volume of total stand in $\mathrm{m}^{3} \cdot \mathrm{ha}^{-1}$ :

$$
V_{t}=V_{m}+V_{r}
$$

15. $\mathrm{BA}_{t}=$ basal area of total stand in $\mathrm{m}^{2} \cdot \mathrm{ha}^{-1}$ :

$$
B A_{t}=B A_{m}+B A_{r}
$$

16. $\mathrm{N}_{\mathrm{t}}=$ stem number of total stand in $\mathrm{ha}^{-1}$ :

$$
N_{t}=N_{m}+N_{r}
$$

17. Cumulative volume of intermediate cuttings $=$ total volume of removing stands in $\mathrm{m}^{3} \cdot \mathrm{ha}^{-1}$

18.

where

$$
\mathrm{SIC}=\frac{\mathrm{CVIC}}{\mathrm{CTV}} \cdot 100(\%)
$$

$$
\begin{array}{ll}
\text { SIC - } & \text { share of intermediate cuttings } \\
\text { CVIC - } & \text { Cumulative volume of } \\
& \text { intermediate cuttings } \\
\text { CTV - Cumulative total volume }
\end{array}
$$

19. Cumulative total volume $\left(\sum V_{t}\right)=$ volume of total stand $\left(V_{t}\right)$ in age $A+$ volume of removal stand $\left(V_{r}\right)$ in age $A-5$ in $\mathrm{m}^{3} \cdot \mathrm{ha}^{-1}$

20. Mean annual increment of cumulative total volume $=\left(\Sigma V_{t}\right) \cdot A^{-1}$ in $\mathrm{m}^{3} \cdot \mathrm{ha}^{-1} \cdot \mathrm{yr}^{-1}$

21. Current increment of cumulative total volume $=$ one year increment of $(\Sigma \mathrm{Vt})$ in five year intervals in $\mathrm{m}^{3} \cdot \mathrm{ha}^{-1} \cdot \mathrm{yr}^{-1}$.

22. When using the yield table for determining 
the actual volume per ha (Vact) of a stand, a basal area ratio is to be recommended:

$V_{a c t}=V_{t a b} \cdot B A_{a c t} \cdot B A_{t a b}^{-1}$

where:

$\mathrm{V}_{\mathrm{tab}}=$ volume of the stand by yield table according to the age and yield class,

$\mathrm{BA}_{\text {act }}=$ actual basal area of the stand per ha,

$\mathrm{BA}_{\text {tab }}=$ basal area by yield table according to the age and yield class of the stand.

For determining the actual basal area the stem number and the diameter at breast height can be used by calculation or by using one of the known measuring devices directly.

The rates of percentage difference related to the stem number of main stand in decreasing order of yield classes (with its deterioration) at age of 30 is the following: $92.3-91.4-90.1-$ $89.6-88.5-87.1$. The main correlations of the yield table are presented in graphical form, too.

Figures 3.a to 3.e show the height, DBH, and volume indices for main stand as well as the total volume and the mean annual increment of total volume indices in function of age and yield class.

FIGURE 3. a-e. Data of stand structure and yield of black locust (Robinia pseudoacacia L.) stands as a function of the age

a)

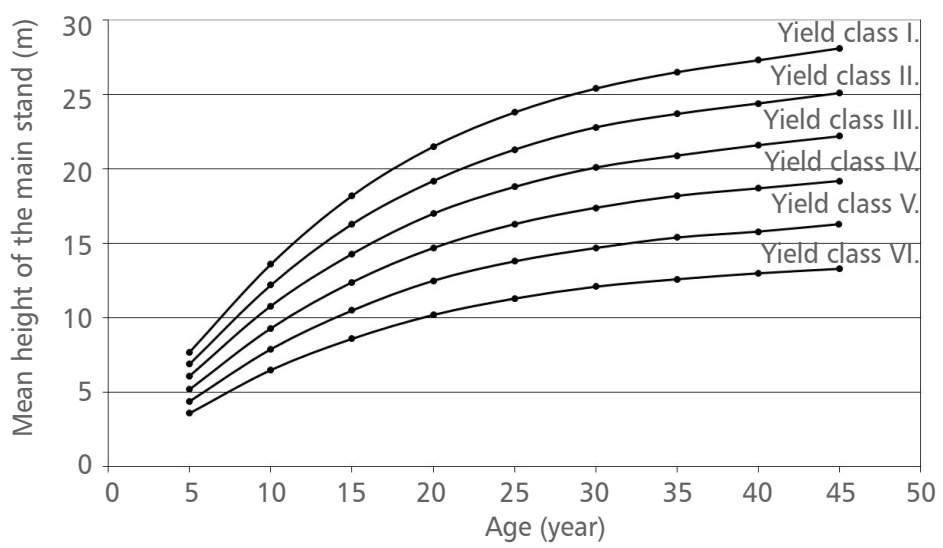

b)

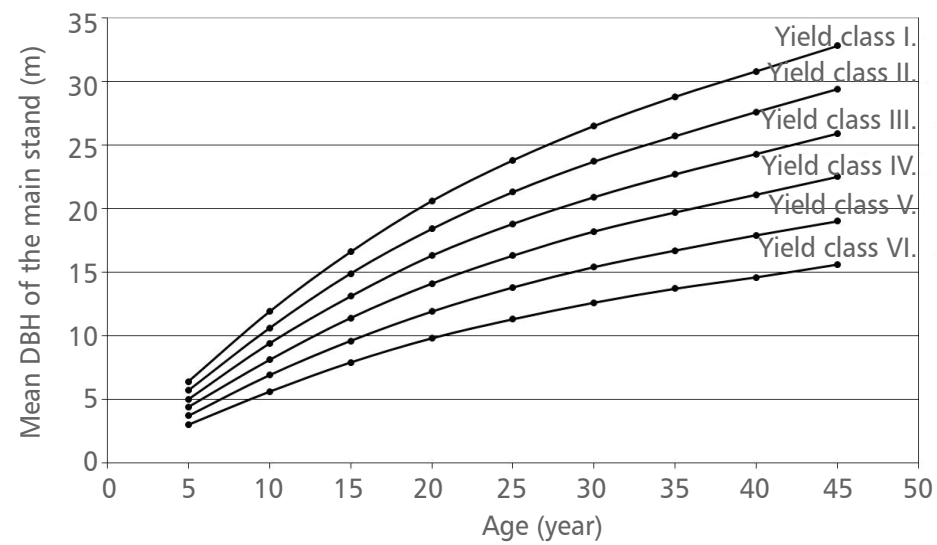


FIGURE 3. a-e. Data of stand structure and yield of black locust (Robinia pseudoacacia L.) stands as a function of the age - continuation

c)

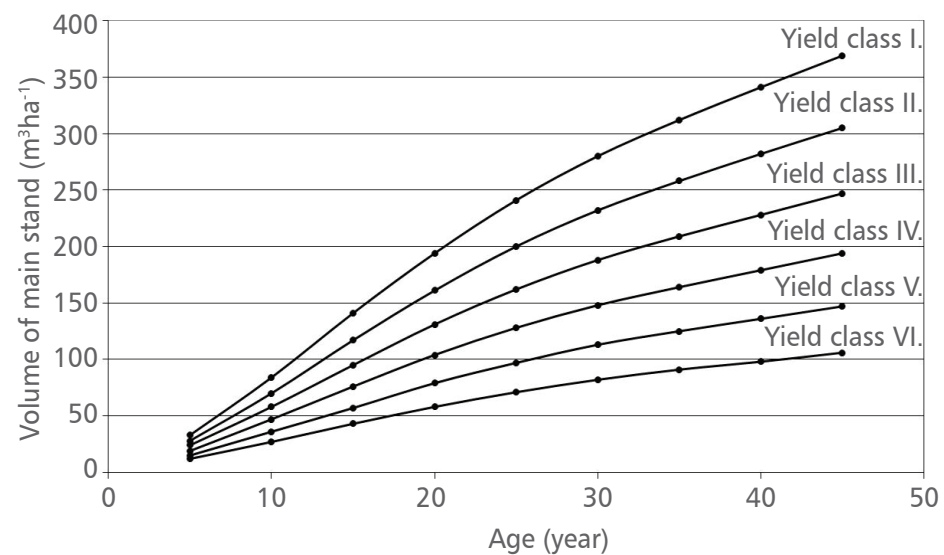

d)

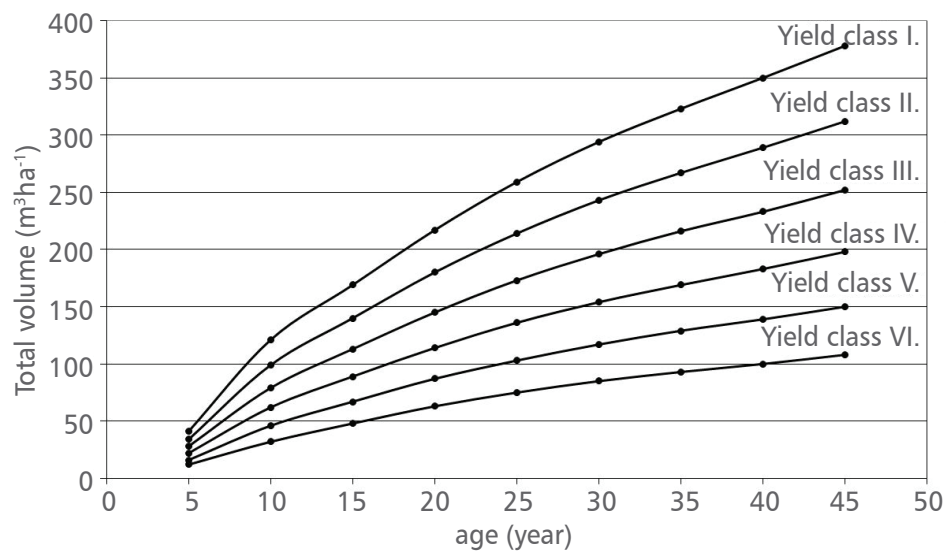

e)

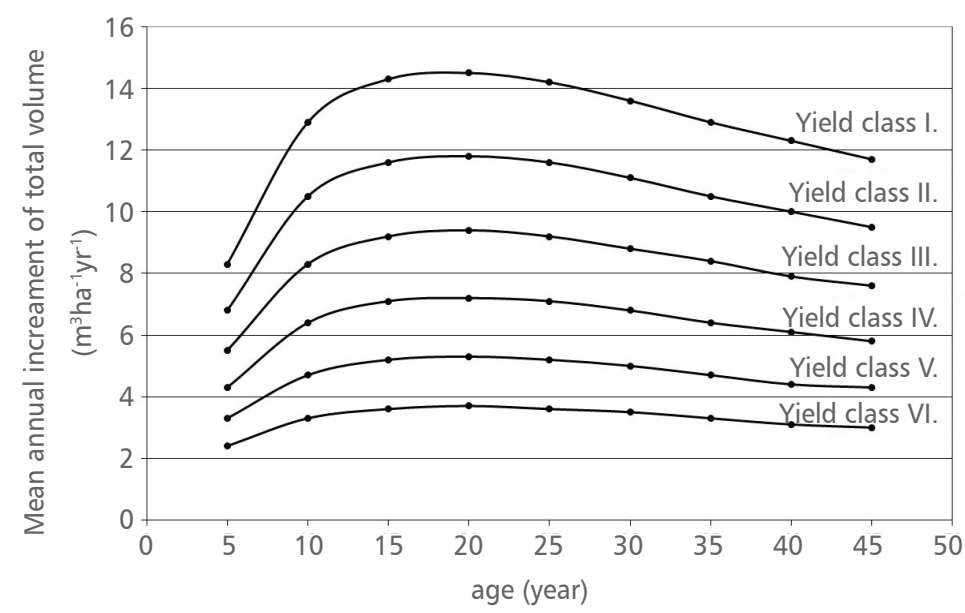




\section{DISCUSSION AND CONCLUSIONS}

Height $=f($ age) is the fundamental relationship for the construction of the yield table presented in this paper. It states that forest stands at a given site follow a particular height development with age. The stand age - stand height scatter plot obtained from the monitoring plot data is divided into a number of height curves, which form the basis for the yield table construction. As the height curves are used for assigning stands to site quality classes-site index (yield classes) we also call the above-mentioned relationship the yield classes assigning one. Despite some resistance in the beginning, the use of stand age and height for the estimation of stand productivity has become so prevalent that the concepts site index and yield class are rarely distinguished from one another today. The yield table constructed by us can be regarded as a "traditional standardised computer supported yield model" where the stand development was modelled from stand level data. Black locust yield table presented in this paper is the first local work in the history of the Hungarian black locust research. The programmable editing procedure allows extension and formal change of information content of the yield table according to different demands. This type of yield tables (standards) somewhat reflects the local growing- technological (forest tending) specialities better way, on the other hand refer to the trend of quality and quantity changing of black locust stands growing in a given area. This fact has already been proved by the Hungarian forest inventory practice.

The yield table can be successfully utilized in the following fields:

- appraisal of statistical nature of the black locust stands,

- harvest scheduling of black locust stands, implementing the volume estimations,

- elaborating and further developing silvicultural (tending operation) models for black locust stands,

- elaborating and explaining the guidelines of the tree species policy and,

- evaluation of sprouting criterion of black locust stands based on yield.

In the past decades some new methods have been developed for construction of yield models. Individual-tree, small area or gap, matter balance as well as landscape models have primarily served as research tools to date [33]. But most of this type models can be characterized with increasing demand for information about the reaction of forest ecosystems to changing ecological conditions which needs much more comprehensive research than we have done until now.

\section{REFERENCES}

1. FÜHRER E, RÉDEI K 2003 The role of black locust (Robinia pseudoacacia L.) in the Great Hungarian Plain. Proceedings of Scientific Papers 2. Sofia 67-73

2. RÉDEI K 2006 The biological basics and practice of the growing-improvement of black locust (in Hungarian). Agroinform Kiadó Budapest

3. KERESZTESI B 1986 Black locust growing in short rotation (in Hungarian). Erdészeti Kutatások 78: 1528

4. RÉDEI K 1995 The effect of increment thinnings on the changing of yield and value of black locust (Robinia pseudoacacia L.) stands (in Hungarian). Erdészeti Kutatások 85: 79-90
5. RÉDEI K 1997 The Effect of Regeneration Methods on the Yield of Black Locust (Robinia pseudoacacia L.) Stands in Hungary. Silva Lusitana 5 (1): 71-77

6. RÉDEI K 2005 Yield criterion of choice of black locust regeneration method based on root suckers (in Hungarian). Erdészeti Lapok 140 (11): 324-325

7. RÉDEI K, OSVÁTH-BUJTÁS Z, VEPERDI I 2008 Black Locust (Robinia pseudoacacia L.) Improvement in Hungary: a Review. Acta Silvatica and Lignaria Hungarica 4: 127-132

8. RÉDEI K, MEILBY H 2009 Effect of Thinning on the Diameter Increment in Black Locust (Robinia pseudoacacia L.) Stands. Acta Silvatica and Lignaria Hungarica 5:63-74 
9. RÉDEI K 2003 Bewirtschaftung und Verbesserung von Robinie (Robinia pseudoacacia) in Ungarn. Die Holzzuhcht 12: 15-17

10. RÉDEI K, CSIHA I, KESERÜ ZS 2011 Black Locust (Robinia pseudoacacia L.) Short-Rotation Crops under Marginal Site Conditions. Acta Silvatica and Lignaria Hungarica 7: 125-132

11. BONGARTEN B C, MERKLE S A, HANOVER J W 1991 Genetically improved black locust for biomass production in short-rotation plantations. In: Klass D L (ed) Energy from Biomass and Wastes XV. Institute of Gas Technology, Chicago, IL, USA, pp 391-409

12. BONGARTEN B C, HUBER D A, APSLEY D K 1992 Environmental and genetic influences on shortrotation biomass production of black locust (Robinia pseudoacacia L.) in the Georgia Piedmont. Forest Ecol Manage 55 (1-4): 315-331. DOI: http://dx.doi. org/10.1016/0378-1127(92)90108-L

13. DINI-PAPANASTASI O, PANETSOS C P 2000 Relation between growth and morphological traits and genetic parameters of Robinia pseudoacacia var. monophylla DC in northern Greece. Silvae Genet 49: 37-44

14. BÖHM CH, QUINKENSTEIN A, FREESE D 2011 Yield prediction of young black locust (Robinia pseudoacacia L.) plantation for woody biomass production using allometric relations. Ann For Res 54 (2): 215-227

15. LIESEBACH H, YANG M S, SCHNECK V 2004 Genetic diversity and differentiation in a black locust (Robinia pseudoacacia L.) progeny test. Forest Genetics 11 (2): 151-161

16. CHALUPA V 1992 Tissue culture propagation of black locust. In: Hanover J W, Miller K, Plesko S (eds) Black locust: Biology, Culture and Utilization. Michigan State University, East Lansing, Michigan, USA, pp 115-125

17. KRASZKIEWICZ A 2013 Evaluation of the possibility of energy use black locust (Robinia pseudoacacia L.) dendromass acquired in forest stands growing on clay soils. Journal of Central European Agriculture 14 (1): 388-399. DOI: http://dx.doi.org/10.5513/ JCEA01/14.1.1212

18. DENGIZ O, GOL C, SARIOGLU F E, EDIS S 2010 Parametric approach to land evaluation for forest plantation: A methodological study using GIS model. Afr J Agric Res 5 (12): 1482-1496

19. SHARMA K R 2000 Variation in wood characteristics of Robinia pseudoacacia L. managed under high density short rotation system. In: IUFRO World Congress, Malaysia
20. SWAMY S L, PURI S, KANWAR K 2002 Propagation of Robinia pseudoacacia Linn. and Grewia optiva Drummond from rooted stem cuttings. Agroforest Syst 55 (3): 231-237. DOI: http://dx.doi. org/10.1023/A:1020579516144

21. DUNLUN Z, ZHENFEN Z, FANGQUAN W 1995 Progress in clonal selection and breeding of black locust (Robinia pseudoacacia L.). In: Forest Tree Improvement in the Asia-Pacific Region (Xihuan Shen). China Forestry Publishing House, Beijing, China, pp 152-156

22. LEE K J, SOHN J H, RÉDEI K, YUN H Y 2007 Selection of Early and Late Flowering Robinia pseudoacacia from Domesticated and Introduced Cultivars in Korea and Prediction of Flowering Period by Accumulated Temperature. Journal of Korean Forest Society 96 (2): 170-177

23. RÉDEI K, CSIHA I, KESERÜ ZS, GÁL J 2012 Influence of Regeneration Method on the Yield of Black Locust (Robinia pseudoacacia L.) Stands: a Case Study. Acta Silvatica and Lignaria Hungarica 8 (1): 103-111. DOI: http://dx.doi.org/10.2478/v10303-012-0008-1

24. FEKETE $Z 1937$ Black locust yield tables for the Great Hungarian Plane (in Hungarian). Sopron, Hungary

25. FEKETE $Z 1960$ Results of re-survey of black locust stands (in Hungarian). Erdészeti Kutatások 56: 3-43

26. RÉDEI K 1984 Yield of black locust stands (in Hungarian). FRI Research report, Kecskemét, Hungary

27. SOPP L, KOLOZS L 2000 Volume tables. Forest Service, Budapest, Hungary, pp 58-66

28. BIRLANESCU E 1977 Certetari provind ameloiorarea salcinului (Robinia pseudoacacia L.). Studii si cercatari Silvicultura Bucuresti 3: 441-453

29. BRIDGEN M R 1992 Plantation silviculture of black locust. In: Hanover J W, Miller K, Plesko S (eds) Black locust: Biology, Culture and Utilization. Michigan State University, East Lansing, Michigan, USA, pp 2132

30. KOHÁN S 2007 Niektoré vysledky hodnotenia rastu a objemovej produkcie agáta bieleho (Robinia pseudoacacia L.) pri rozlicnych sposoboch pestovania v oblasti vychodoslo-venskej níziny. Lesnícky casopis Forestry Journal 53:107-116

31. PARK Y G 1996 The prospects for the utilisation of Robinia pseudoacacia in Korea. Kor J Apicult 11: 2557

32. RÉDEl K, GÁL J 1985 Yield of black locust stands (in Hungarian). Erdészeti Kutatások 76-77: 195-203

33. PRETZSCH H 2009 Forest Dinamics, Growth and Yield. Springer-Verlag Berlin Heidelberg, Germany, pp 490-491. DOI: http://dx.doi.org/10.1007/978-3-54088307-4 